\title{
MEASUREMENT AND CORRELATION OF ISOBARIC VAPOR-LIQUID EQUILIBRIUM DATA FOR WATER + 2-AZIDO-N,N- DIMETHYLETHANAMINE SYSTEM AT 4 kPa
}

\author{
Hosein Rouhandeh ${ }^{1}$, Shahram Ghanbari Pakdehi, ${ }^{1,}$
}

https://doi.org/10.23939/chcht15.02.226

\begin{abstract}
Isobaric vapor-liquid equilibrium (VLE) data for binary system of water + 2-azido-N,N-dimethylethanamine (DMAZ) was measured at $4 \mathrm{kPa}$. The results showed an azeotropic point at $x_{1}=0.985$ and $T=$ $=302.17 \mathrm{~K}$. The data was correlated with nonrandom two-liquid (NRTL), Wilson and universal quasi-chemical activity coefficient (UNIQUAC) models for the liquid phase. A comparison of the model performances was made using of the criterion of the average absolute deviation, standard deviation and mean standard deviation in boiling-point temperature. The results indicated that the NRTL activity coefficient model satisfactorily correlated the VLE data.
\end{abstract}

Key words: 2-azido-N,N-dimethylethanamine, vaporliquid equilibrium, azeotrope, NRTL.

\section{Introduction}

Liquid fuels have been used for rocket engines in space industries since 1949. Among the liquid fuels, hydrazine family (containing anhydrous hydrazine $(\mathrm{AH})$, monomethyl hydrazine (MMH) and unsymmetrical dimethyl hydrazine (UDMH)) has been used extensively. Seeing that all members of this group are carcinogen [1], chemical engineers pursue safe and high-performance liquid fuels and introduced 2-azido-N,N-dimethylethanamine (DMAZ) as a good replacement for hydrazine fuels [2]. Unlike hydrazine fuels, DMAZ is noncarcinogenic and has desirable properties such as good thermo-physical, energetic, safety, and environmental properties [3].

DMAZ is produced from reaction between aqueous solutions of sodium azide and dimethylaminoethyl chloride. After filtration of the solution and removing impurities, resultant solution contains water and DMAZ [4]. Because of difference in boiling points of DMAZ and water (normal boiling point of DMAZ is $408.15 \mathrm{~K}$ ),

\footnotetext{
${ }^{1}$ Faculty of Chemistry \& Chemical Engineering,

Malek Ashtar University of Technology, P.O. Box: 16765/3454, Tehran, Iran

凶sh_ghanbari73@yahoo.com

(c) Rouhandeh H., Pakdehi S., 2021
}

distillation is a feasible process for DMAZ separation from the resultant solution. Due to the thermal sensitivity of azide functional group $\left(-\mathrm{N}_{3}\right)$ in DMAZ, it is preferred to use vacuum distillation. The vacuum distillation of water + DMAZ binary system at different pressures of 26 , 9, 4 and $2 \mathrm{kPa}$ shows that the water contents of the final product are $0.81,0.3,0.24$ and $0.239 \mathrm{wt} \%$, respectively. So, the vacuum pressure of $4 \mathrm{kPa}$ is selected as the proper condition. Vapor-liquid equilibrium (VLE) data is necessary for design and development of efficient distillation process $[5,6]$. In other words, an abundance of experimental VLE data is needed for accurate design of separation processes and facilities [7].

The presence of some specific atoms (such as oxygen in water and nitrogen in DMAZ) leads to form a non-ideal system [8-10]. VLE data is used to determine activity coefficients and calculate the deviations of the mixture from ideal behavior [11]. There are various models to estimate the VLE of non-ideal systems. However, the VLE data needs to be determined experimentally for new systems, especially in the final design step [12-14].

There is no VLE data for water + DMAZ binary system in literature. In this work, isobaric VLE data at $4 \mathrm{kPa}$ will be determined for the mentioned system. The experimental data will be correlated for the liquid-phase activity coefficients by means of Wilson, nonrandom two liquid (NRTL) and universal quasi-chemical (UNIQUAC) models. Also, the correlated parameters of the models are given. Finally, the most suitable equation will be introduced. The results will be helpful for safe design of industrial vacuum distillation column for DMAZ purification.

\section{Experimental}

\subsection{Chemicals}

DMAZ was purchased from 3M Company (USA), with purity higher than $99.960 \%$. The DMAZ structure is shown in Fig. 1. Moreover, the redistilled water (conductivity of $0.9 \mu \mathrm{S}$ measured with Metrohm $\mathrm{pH} /$ Conductometer) was used. 
<smiles>CN(C)CCN=[N+]=[N-]</smiles>

Fig. 1. Structure of DMAZ molecule

The purity of the components was checked on the basis of their refractive index at $298.15 \mathrm{~K}$. The refractive index was measured using a thermostatically controlled refractometer (OPTECH, Germany) equipped with a digital thermometer, with an uncertainty of $\pm 0.01 \mathrm{~K}$ and $\pm 0.001 n_{\mathrm{D}}$. The measured physical properties are listed in Table 1 along with the values from the literature [15]. Boiling point measurements were conducted by means of a Fischer boiling-point measurement system (model VLE100, Fischer America, USA). The estimated uncertainty in boiling point measurements was $0.01 \mathrm{~K}$.

Table 1

Normal boiling temperature and refractive index of DMAZ

\begin{tabular}{|c|c|}
\hline Property & DMAZ \\
\hline $\mathrm{T}^{\mathrm{lit}} \mathrm{b}, \mathrm{K}$ & $408.15[18]$ \\
\hline$T^{\operatorname{xpp}}{ }_{b}, \mathrm{~K}$ & 408.25 \\
\hline$n^{h t}{ }_{D}$ & $1.438[18]$ \\
\hline$n^{\exp }{ }_{D}$ & 1.448 \\
\hline
\end{tabular}

\subsection{Apparatus and Procedure}

In the dynamic equilibrium still (model VLE 602/50, i-Fischer Engineering, Germany), the binary mixture was brought to a boil under controlled pressure. The equilibrium still of about $250 \mathrm{~cm}^{3}$ in volume was equipped with a propeller agitator to sufficiently mix the liquid mixture. Using a vacuum pump, the pressure was fixed and held constant. In each VLE experiment, the vapor and liquid mixture was separated in the equilibrium glass cell, and the vapor phase was condensed and returned to the boiling cell. The composition of the boiling liquid and the vapor changed with time until a steady state was achieved. The system was kept at the boiling point at least for $20 \mathrm{~min}$ to ensure that the steady state was reached. Then, $0.2 \mathrm{~cm}^{3}$ of the samples of liquid and condensate were taken by a scaled syringe for analysis. This was repeated for three times for each sample. The equilibrium compositions were determined with the refractometry method. The refractometer was frequently calibrated using the redistilled water. Water was circulated into the instrument through a thermostatically controlled bath maintained constant temperature to $\pm 0.01 \mathrm{~K}$. At least, three analyses were made for each sample. The maximum deviations from the average value were less than $0.1 \%$.

The uncertainties of the pressure, equilibrium composition measurements and temperature were $\pm 0.001 \mathrm{kPa}, \pm 0.001$ and $\pm 0.01 \mathrm{~K}$, respectively. All temperatures were measured by calibrated temperature sensors (model DC30, Thermo Scientific Haake). The vapor pressure of the pure DMAZ was measured with the same recirculating still.

\section{Results and Discussion}

\subsection{Calibration of Refractometer for Water+DMAZ System}

The measured refractive index data for the binary mixture of water+DMAZ at $298.15 \mathrm{~K}$ is represented in Table 2. To obtain the data, refractive index of pure DMAZ and redistilled water were measured by the refractometer. Then, certain moles of DMAZ and water were mixed. After that, the refractive indexes for different certain mixtures of water + DMAZ were recorded. The refractive indexes of the investigated mixtures were related to mole compositions of water + DMAZ.

Table 2

\section{Experimental refractive index of water+DMAZ binary mixture at $298.15 \mathrm{~K}$}

\begin{tabular}{|c|c|}
\hline$x_{1}$ & $n_{D}{ }^{a}$ \\
\hline 0.000 & 1.448 \\
\hline 0.058 & 1.440 \\
\hline 0.101 & 1.437 \\
\hline 0.147 & 1.431 \\
\hline 0.190 & 1.429 \\
\hline 0.275 & 1.420 \\
\hline 0.360 & 1.412 \\
\hline 0.411 & 1.407 \\
\hline 0.477 & 1.400 \\
\hline 0.556 & 1.392 \\
\hline 0.613 & 1.387 \\
\hline 0.684 & 1.379 \\
\hline 0.748 & 1.373 \\
\hline 0.805 & 1.359 \\
\hline 0.845 & 1.353 \\
\hline 0.922 & 1.345 \\
\hline 0.950 & 1.341 \\
\hline 0.985 & 1.336 \\
\hline 1.000 & 1.334 \\
\hline
\end{tabular}

Note: ${ }^{a}$ Numerical error limit for $n_{D}$ is \pm 0.001

\subsection{Vapor Pressure of Pure DMAZ}

Vapor pressure of pure DMAZ was measured in the temperature range from 302.20 to $317.30 \mathrm{~K}$ (Table 3 ). This was performed for water in the temperature range which was confirmed with literature data [16]. 
Table 3

Experimental vapor pressures of pure DMAZ and water at different temperatures

\begin{tabular}{|c|c|c|}
\hline $\mathrm{T}, \mathrm{K}$ & $P_{D M A Z}, \mathrm{kPa}^{a}$ & $P_{\text {water }} \mathrm{kPa}^{a}$ \\
\hline 317.30 & 4.006 & 9.150 \\
\hline 316.60 & 3.552 & 8.824 \\
\hline 314.89 & 3.193 & 8.070 \\
\hline 313.84 & 2.928 & 7.633 \\
\hline 312.84 & 2.553 & 7.239 \\
\hline 310.89 & 2.123 & 6.518 \\
\hline 309.88 & 1.706 & 6.169 \\
\hline 307.48 & 1.219 & 5.404 \\
\hline 306.50 & 0.883 & 5.116 \\
\hline 304.36 & 0.783 & 4.536 \\
\hline 303.02 & 0.732 & 4.200 \\
\hline 302.73 & 0.651 & 4.131 \\
\hline 302.47 & 0.627 & 4.070 \\
\hline 302.29 & 0.618 & 4.027 \\
\hline 302.25 & 0.586 & 4.018 \\
\hline 302.22 & 0.558 & 4.011 \\
\hline 302.20 & 0.526 & 4.006 \\
\hline 302.17 & 0.524 & 3.999 \\
\hline 302.16 & 0.523 & 3.997 \\
\hline
\end{tabular}

Note: ${ }^{a}$ Numerical error limit for $P$ is \pm 0.001

\subsection{Isobaric VLE}

Distillation processes are carried out more nearly at constant pressure than constant temperature. So VLE data was measured at $4 \mathrm{kPa}$ for water + DMAZ binary system. The obtained results are shown in Table 4. The VLE data include vapor phase and liquid phase compositions, temperature, liquid-phase activity coefficients and excess molar Gibbs energy.

From the data in Table $4, \ln \gamma_{i}$ versus $x_{i}$ for two components DMAZ and water was plotted. The experimental liquid-phase activity coefficient of component $i$ was evaluated by the following equation:

$$
\gamma_{i}=\frac{y_{i} P}{x_{i} P_{i}^{\text {sat }}}
$$

where $y_{i}, x_{i}, P$ and $P_{i}^{\text {sat }}$ are the gas phase mole fraction, the liquid phase mole fraction, the total pressure and the saturated pressure of component $i$, respectively. Eq. (1) was used to calculate the experimental liquid-phase activity coefficient assuming that the vapor phase behaves as an ideal gas at low experimental pressure [16]. Values of $\ln \gamma_{1}$ and $\ln \gamma_{2}$ were calculated for each data point and then combined according to Eq. (2), written for the excess molar Gibbs energy in the binary system:

$$
\frac{G^{E}}{R T}=\sum x_{i} \ln \gamma_{i}=x_{1} \ln \gamma_{1}+x_{2} \ln \gamma_{2}
$$

Table 4

Experimental VLE data for water + DMAZ binary system at $4 \mathrm{kPa}$

\begin{tabular}{|c|c|c|c|c|c|}
\hline $\mathrm{T}, \mathrm{K}$ & $x_{1}$ & $y_{1}$ & $\gamma_{1}$ & $\gamma_{2}$ & $G^{E} / R T$ \\
\hline 317.30 & 0.000 & 0.000 & $\gamma^{\infty}$ & 1.0000 & 0.0000 \\
\hline 316.60 & 0.025 & 0.134 & 2.4297 & 1.0002 & 0.0224 \\
\hline 314.89 & 0.050 & 0.241 & 2.3891 & 1.0009 & 0.0444 \\
\hline 313.84 & 0.071 & 0.319 & 2.3545 & 1.0014 & 0.0621 \\
\hline 312.84 & 0.102 & 0.425 & 2.3023 & 1.0032 & 0.0879 \\
\hline 310.89 & 0.151 & 0.546 & 2.2190 & 1.0075 & 0.1267 \\
\hline 309.88 & 0.198 & 0.653 & 2.1384 & 1.0145 & 0.1620 \\
\hline 307.48 & 0.291 & 0.776 & 1.9738 & 1.0367 & 0.2234 \\
\hline 306.50 & 0.358 & 0.849 & 1.8542 & 1.0655 & 0.2617 \\
\hline 304.36 & 0.471 & 0.881 & 1.6495 & 1.1492 & 0.3093 \\
\hline 303.02 & 0.608 & 0.902 & 1.4129 & 1.3661 & 0.3324 \\
\hline 302.73 & 0.705 & 0.919 & 1.2622 & 1.6871 & 0.3185 \\
\hline 302.47 & 0.812 & 0.928 & 1.1232 & 2.4432 & 0.2623 \\
\hline 302.29 & 0.881 & 0.936 & 1.0553 & 3.4810 & 0.1959 \\
\hline 302.25 & 0.911 & 0.945 & 1.0327 & 4.2183 & 0.1574 \\
\hline 302.22 & 0.934 & 0.954 & 1.0186 & 4.9962 & 0.1234 \\
\hline 302.20 & 0.955 & 0.965 & 1.0090 & 5.9147 & 0.0885 \\
\hline 302.16 & 0.975 & 0.977 & 1.0028 & 7.0363 & 0.0515 \\
\hline 302.17 & 0.985 & 0.985 & 1.0003 & 7.6336 & 0.0307 \\
\hline 302.20 & 1.000 & 1.000 & 1.0000 & $\gamma_{2}^{\infty}$ & 0.0000 \\
\hline
\end{tabular}


Fig. 2 is the temperature-composition phase diagram or bubble-dew point diagram at $4 \mathrm{kPa}$ for the binary system of water + DMAZ. As it is shown in this figure, the binary

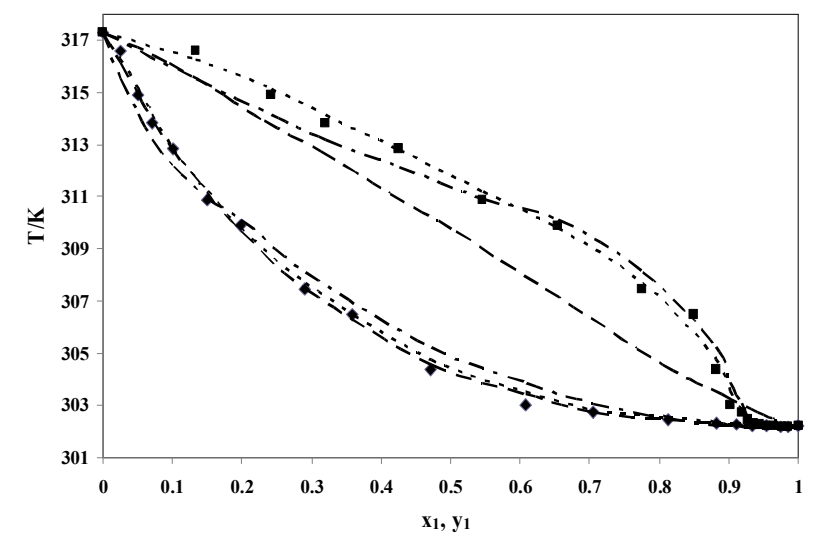

Fig. 2. $T-x_{1}-y_{1}$ curve for the binary system water $+D M A Z$ at $4 \mathrm{kPa}$ : bubble-exp (४);

dew-exp (ロ); NRTL (- - ); Wilson (- - -);

UNIQUAC $(--\cdots)$ system has a minimum boiling azeotrope. The azeotropic composition for the system was obtained by determining the $x_{1}$ value that makes $\left(x_{1}-y_{1}\right)$ to be zero (Fig. 3).

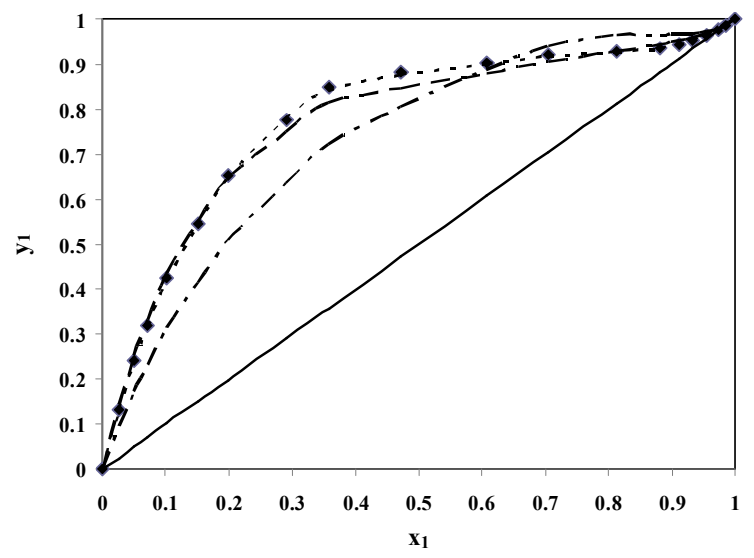

Fig. 3. $x_{1}-y_{1}$ plot for the binary system water + DMAZ at $4 \mathrm{kPa}$ : exp (४); NRTL (- - -); Wilson (- - -); UNIQUAC (-- - )

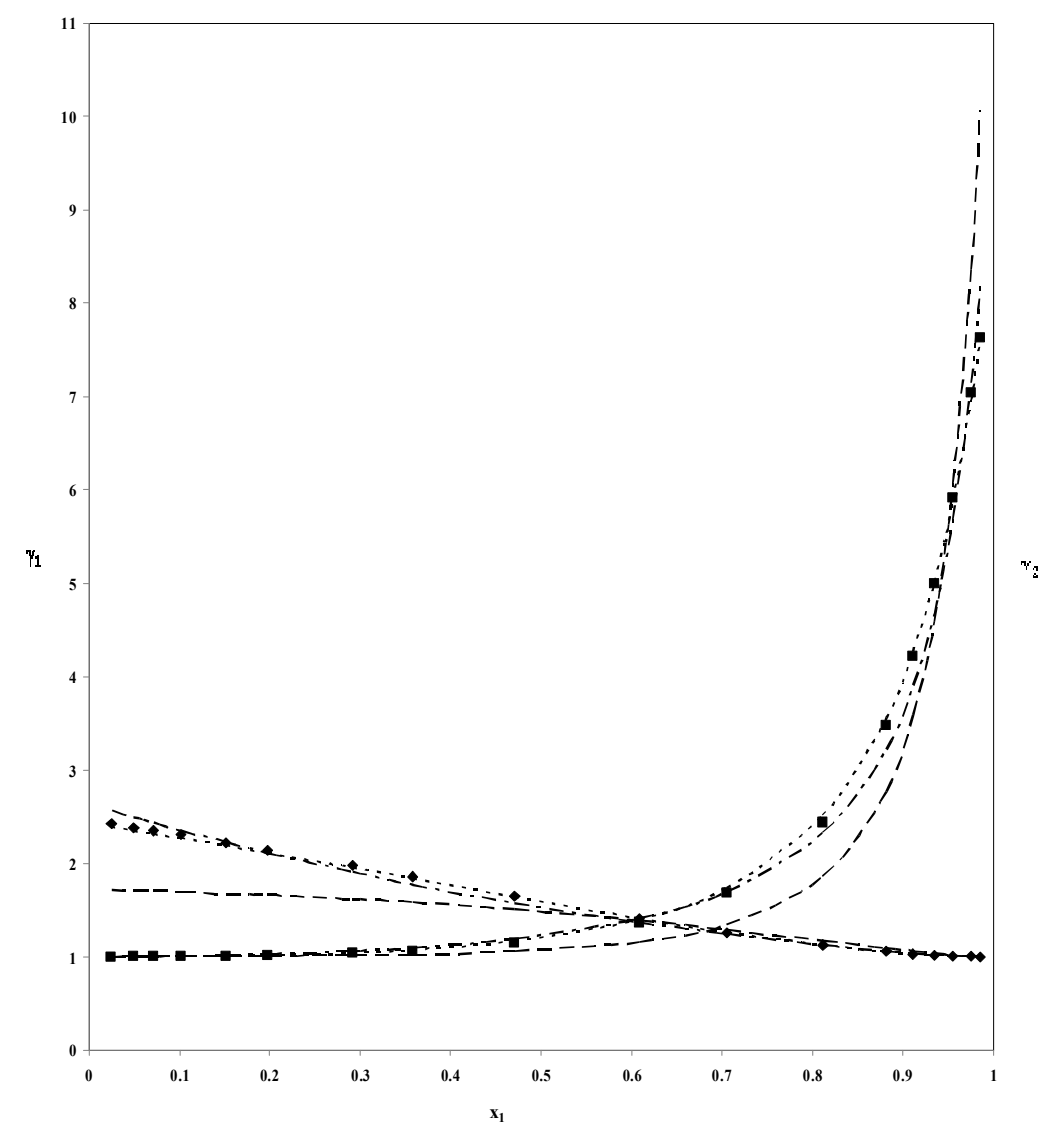

Fig. 4. Experimental data and the fitting curves for the models of $\gamma_{1}$ for the binary system water + DMAZ at $4 \mathrm{kPa}$ : $\gamma_{1}-\exp (\diamond) ; \gamma_{2}-\exp (\mathbf{\square}) ; \operatorname{NRTL}(---)$; Wilson $(---)$;UNIQUAC (- - - ) 


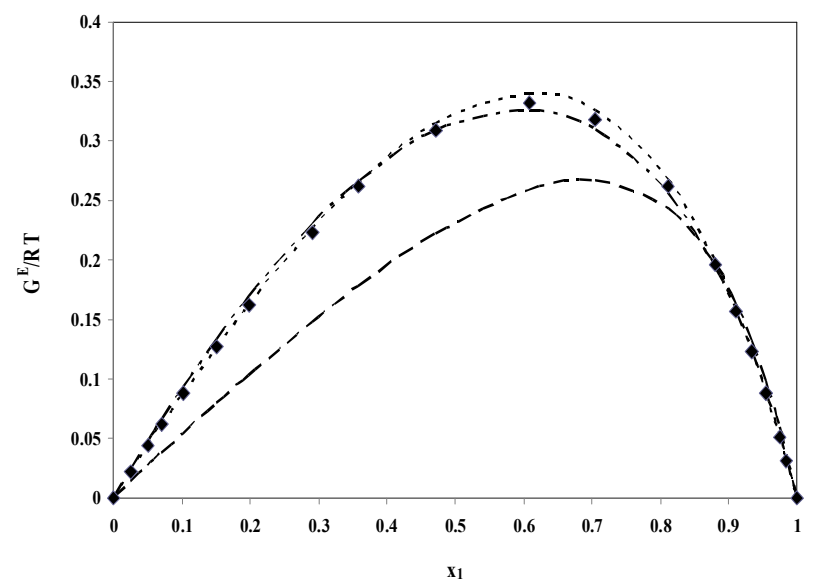

Fig. 5. Excess molar Gibbs energy $G^{E} / R T$ for the binary system water + DMAZ at $4 \mathrm{kPa}$ : exp (४);NRTL (- - -); Wilson (- - - ); UNIQUAC ( $-\longrightarrow)$

The values of activity coefficient calculated from experimental data indicate a positive deviation from ideal behavior. The experimental $\gamma_{1}$ and $\gamma_{2}$ were compared to those calculated with Wilson, NRTL and UNIQUAC models in Fig. 4. According to this figure, the activity coefficient data was best correlated by NRTL model.

For excess molar Gibbs energy, the comparison of the experimental data with those calculated by Wilson, UNIQUAC, and NRTL models are shown in Fig. 5.

During the period of the VLE experiment, thermal stability of DMAZ was checked by a calibrated gas chromatograph (Agilent model 6890) equipped with FID detector. No peak except DMAZ was observed. So, DMAZ is stable in the temperature range of $302.16-$ $317.30 \mathrm{~K}$ and $4 \mathrm{kPa}$.

Correlation parameters, average absolute deviation (AAD), standard deviation (SD) and mean standard deviation (MSD) for boiling temperatures and vapor-phase mole fractions of the water + DMAZ system at $4 \mathrm{kPa}$ for NRTL, Wilson and UNIQUAC models are given in Table 5. AAD-y and AAD-T, SD-y, SD-T, MSD- $y$ and MSD-T are:

$$
\begin{gathered}
A A D-y=\frac{\sum_{i=1}^{N}\left|y_{i}-y_{i}^{c a l}\right|}{N} \\
A A D-T=\frac{\sum_{i=1}^{N}\left|T_{i}-T_{i}^{c a l}\right|}{N} \\
S D-y=\left(\frac{\sum_{i=1}^{N}\left(y_{i}-\bar{y}\right)^{2}}{N}\right)^{0.5} \\
S D-T=\left(\frac{\sum_{i=1}^{N}\left(T_{i}-\bar{T}\right) 2}{N}\right)^{0.5} \\
S M D-y=\frac{\left(\sum_{i=1}^{N}\left(y_{i}-\bar{y}\right)^{2}\right)^{0.5}}{N}
\end{gathered}
$$

$$
S M D-T=\frac{\left(\sum_{i=1}^{N}\left(T_{i}-\bar{T}\right)^{2}\right)^{0.5}}{N}
$$

where $N$ is number of data point; $y_{i}$ and $y_{i}^{c a l}$ are experimental and calculated vapor-phase mole fraction, respectively.

The azeotrope concentration for NRTL, Wilson, UNIQUAC equations is compared to experimental data (Table 6). In Table 6, the temperature at which azeotrope occurs is also given. As it is shown, NRTL model satisfies experimental results.

The thermodynamic consistency of the experimental data was checked by means of the Gibbs-Duhem test method [17]. The Gibbs-Duhem equation for this purpose is given below [18]:

$$
\sum x_{i} d \ln \gamma_{i}=0
$$

Experimental errors may cause deviation of the activity coefficients (drawn from the VLE data) from the Gibbs-Duhem equation. Therefore, thermodynamic consistency of the experimental results was evaluated via two tests: (1) the Herington method and (2) point-to-point van Ness method [13, 17, 19-22]. According to the former test method, the experimental data is thermodynamically consistent if, from $\ln \left(\gamma_{1} / \gamma_{2}\right)$ vs. $x_{1}$ plots, the value of $|D-J|$ is less than 10 . The values of $D$ and $J$ can be calculated using Eqs. (10) and (11). $S_{1}$ is an area under curve above the $x_{1}$ axis and $S_{2}$ is the area below the $x_{2}$ axis under the curve (Fig. 6).

$$
\begin{gathered}
D=100 \cdot \frac{\left(|| S_{1}|-| S_{2} \|\right)}{(|| S 1|+| S 2 \|)} \\
J=150 \cdot\left|\frac{\left(T_{\max }-T_{\min }\right)}{T_{\min }}\right|
\end{gathered}
$$

where $T_{\max }$ and $T_{\min }$ are the highest and the lowest boiling point temperatures in the system, respectively. 
Correlation parameters and AADs for boiling temperatures and vapor-phase mole fractions of the system water + DMAZ at $4 \mathrm{kPa}$

\begin{tabular}{|l|c|c|c|c|c|c|c|c|}
\hline Model & $\Lambda_{12}{ }^{a}$ & $\Lambda_{21}{ }^{a}$ & AAD-y & AAD-T & SD-y & SD-T & SMD-y & SMD-T \\
\hline Wilson & 0.927 & 0.103 & 0.012 & 0.37 & 0.016771 & 0.51313 & 0.00395 & 0.120946 \\
\hline NRTL & 62.650 & -7.240 & 0.003 & 0.16 & 0.004383 & 0.18106 & 0.00103 & 0.048780 \\
\hline UNIQUAC & 15.900 & -15.500 & 0.060 & 2.56 & 0.078620 & 3.63660 & 0.01853 & 0.857150 \\
\hline
\end{tabular}

Notes: ${ }^{a}$ the binary adjustable parameters for various models are as follows: for NRTL $\Lambda_{i j}:\left(g_{i j} g_{i j}\right)$; for Wilson $\Lambda_{i j}:\left(\lambda_{i j}-\lambda_{i i}\right)$; for UNIQUAC $\Lambda_{i j}:\left(u_{i j}-u_{j j}\right)$. The uncertainties of all parameters are \pm 0.001

Table 6

Comparison between the calculated azeotropic concentration and temperature for the models and experimental data for the system water + DMAZ at $4 \mathrm{kPa}$

\begin{tabular}{|c|c|c|c|c|}
\hline & NRTL model & Wilson model & UNIQUAC model & Experimental data \\
\hline Azeotropic concentration $\left(x_{1}=y_{1}\right)$ & 0.986 & 0.987 & 0.988 & 0.985 \\
\hline Azeotropic temperature, $\mathrm{K}$ & 302.17 & 302.19 & 302.16 & 302.17 \\
\hline
\end{tabular}

The calculation result was $|\mathrm{D}-\mathrm{J}|=2.21<10$, which indicates that all experimental data are in accordance with thermodynamic consistency.

The Van Ness point-to-point test calculates the average deviation between experimental and calculated gas phase solute concentration $\left(y_{i}\right)$ of component $i$ and system pressure $(P)$. The criteria for point-to-point test method are listed in Table 7. In this table, $j$ is the data number, $N$ is the total number of the data points, $y_{i}^{c a l}$ and $y_{i}^{\exp }$ are the calculated and experimental vapor phase compositioni of species ' $i$ ' and $P^{c a l}$ and $P^{\exp }$ are the calculated and experimental pressure of the system, respectively. All the experimental data are consistent, as one can see in Table 8.

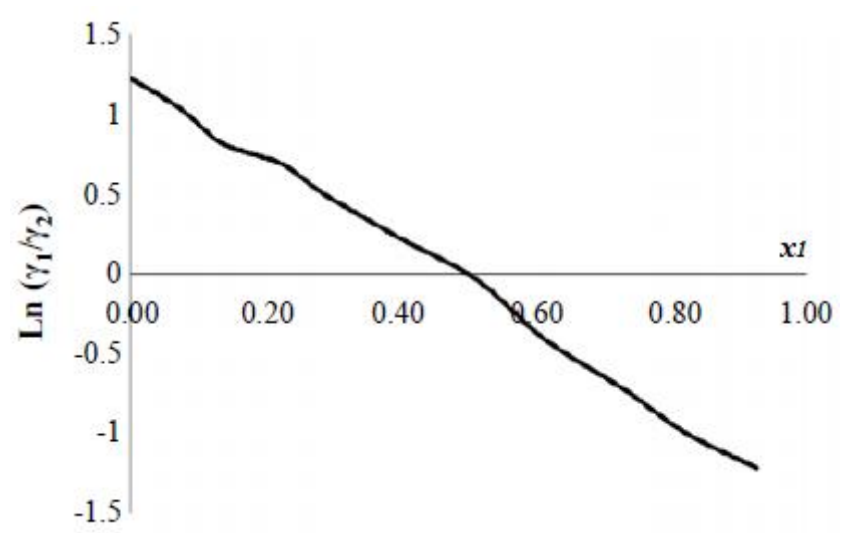

Fig. 6. Consistency by area test

Table 7

Criteria of consistency test for point-to-point method

\begin{tabular}{|c|c|c|}
\hline Parameter & Formula & Criteria \\
\hline Overall deviation in gas phase solute concentration & $\Delta y=\frac{1}{N} \times \sum_{j=1}^{n}\left(y_{i}^{\text {cal }}-y_{i}^{\text {exp }}\right)$ & $\Delta y \leq 0.01$ \\
\hline Overall deviation in total system pressure & $\Delta P=\frac{1}{N} \times \sum_{j=1}^{n}\left(P_{i}^{\text {cal }}-P_{i}^{\text {exp }}\right)$ & $\Delta P \leq 1.33$ \\
\hline
\end{tabular}

Table 8

Results of the thermodynamic consistency for point-to-point method

\begin{tabular}{|c|c|c|}
\hline System & $\Delta y$ & $\Delta P$ \\
\hline Water + DMAZ & $0.0058 \leq 0.01$ & $0.32 \leq 1.33$ \\
\hline
\end{tabular}

\section{Conclusions}

Isobaric VLE data was determined experimentally for water + DMAZ system at $4 \mathrm{kPa}$. The studied system exhibited a positive deviation from ideal behavior. Thus, a minimum boiling azeotrope $\left(x_{1}=y_{1}=0.985\right.$ and $\left.T=302.17 \mathrm{~K}\right)$ occurred in the system. The obtained VLE data was examined by thermodynamic consistency test. The VLE data were correlated by the Wilson, NRTL and UNIQUAC activity coefficient models. The parameters of the activity coefficient models were obtained. The obtained results showed that the NRTL model gave the best results. 


\section{List of abbreviations}

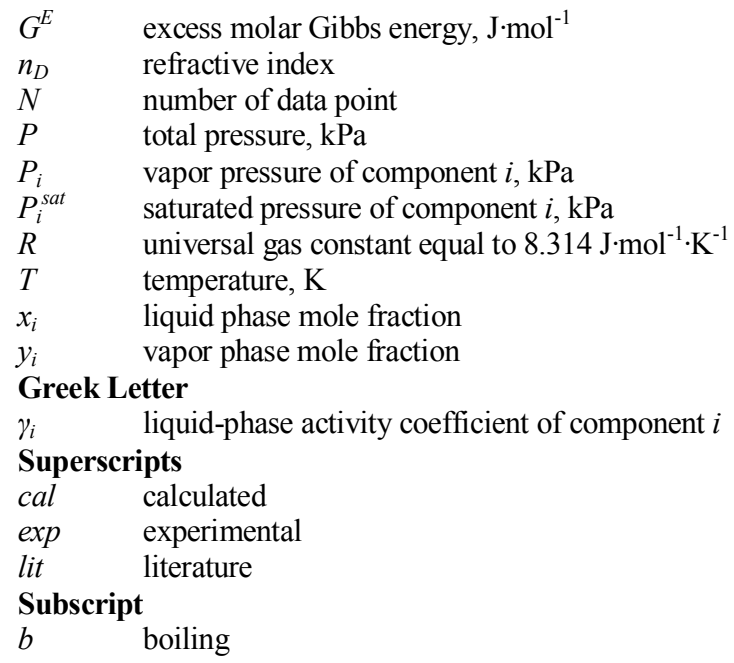

\section{References}

[1] Schmidt E.: Hydrazine and Its Derivatives, $2^{\text {nd }}$ edn. Wiley, New York 2001

[2] Agrawal J.: High Energy Materials: Propellants, Explosives and Pyrotechnics, Wiley-VCH, Weinheim 2010.

[3] Reddy G., Song J., Mecchi M., Johnson M.: Res.-Gen. Tox. En., 2010, 700, 26. https://doi.org/10.1016/j.mrgentox.2010.04.019

[4] Aronson J.: The Synthesis and Characterization of Energetic Materials from Sodium Azide, PhD Thesis, Georgia Institute of Technology 2004

[5] Chouireb N., Crespo E., Pereira L. et al.: J. Chem. Eng. Data, 2018, 63, 2394. https://doi.org/10.1021/acs.jced.7b00945

[6] Li G., Yin X.: J. Chem. Eng. Data, 2018, 63, 2009.

https://doi.org/10.1021/acs.jced.8b00005

[7] Liu L., Zhong Y., Zhang R., Tan W.: J. Chem. Eng. Data, 2015, 60, 3268. https://doi.org/10.1021/acs.jced.5b00500

[8] Figueiredo B., Da Silva F., Silva C.: Ind. Eng. Chem. Res., 2013, 52, 16044. https://doi.org/10.1021/ie402575c

[9] Milzetti J., Nayar D., van der Vegt N.: J. Phys. Chem. B, 2018, 2018, 5515. https://doi.org/10.1021/acs.jpcb.7b11831

[10] Vranes M., Tot A., Papovic S. et al.: J. Chem. Thermodyn., 2015, 81, 66. https://doi.org/10.1016/j.jct.2014.10.002
[11] Torcal M., Langa E., Pardo J. et al. J. Chem. Thermodyn., 2016, 97, 88. https://doi.org/10.1016/j.jct.2016.01.008

[12] Wisniak J., Ortega J., Fernandez L.: J. Chem. Thermodyn., 2017, 107, 216. https://doi.org/10.1016/j.jct.2016.12.027

[13] Ma Y., Gao J., Li M. et al.: J. Chem. Thermodyn., 2018, 122, 154. https://doi.org/10.1021/je400531a

[14] Lemos C., Rade L., Gilfrida W. et al.: J. Chem. Thermodyn. 2018, 123, 46. https://doi.org/10.1016/j.jct.2018.03.023

[15] Kokan T., Olds J., Seitzman J., Ludovice P.: Acta Astronaut., 2009, 65, 967. https://doi.org/10.1016/j.actaastro.2009.01.064

[16] Smith J., Van Ness H.: Introduction to Chemical Engineering Thermodynamics, $4^{\text {th }}$ edn. McGraw-Hill, New York 1987.

[17] Wisniak J., Ortega J., Fernandez L.: J. Chem. Thermodyn., 2017, 105, 385. https://doi.org/10.1016/j.jct.2016.10.038

[18] Poling B., Prausnitz J., O'Connell J.: The Properties of Gases and Liquids, $5^{\text {th }}$ edn. McGraw Hill, New York 2001

[19] Mali N., Yadav S., Ghuge P., Joshi S.: J. Chem. Eng. Data, 2017, 62, 4356. https://doi.org/10.1021/acs.jced.7b00704

[20] Yang J., Pan X., Yu M. et al.: J. Mol. Liq., 2018, 268, 19. https://doi.org/10.1016/j.molliq.2018.07.038

[21] Li M., Xu X., Li X. et al.: Sci. Rep., 2017, 7, 9497. https://doi.org/10.1038/s41598-017-09088-2

[22] Jia H., Wang H., Ma K. et al.: Chin. J. Chem. Eng., 2018, 26, 993. https://doi.org/10.1016/j.cjche.2017.11.003

Received: April 26, 2019 / Revised: May 27. 2019 / Accepted: October 30, 2019

\section{ВИМІРЮВАННЯ ТА КОРЕЛЯЦІЯ ДАНИХ ІЗОБАРИЧНОЇ ПАРО-РІДИННОӤ РІВНОВАГИ ДЛЯ СИСТЕМИ ВОДА + 2-АЗИДО- $N, N$-ДИМЕТИЛЕТАНАМІН ПРИ 4 кПа}

Анотація. Одержані дані ізобаричної паро-рідинної рівноваги (ПРР) для бінарної системи вода +2 -азидо- $N, N-\partial u-$ метилетанамін при 4 кПа. Встановлено, щзо азеотропна точка знаходиться за $x_{I}=0,985$ і $T=302,17$ K. Проведено кореляцію даних з невипадковою дворідинною моделлю (NRTL), моделлю Уілсона та універсальною моделлю коефіцієнта квазіхімічної активності (UNIOUAC) для рідкої фази. Проведено порівняння характеристик моделі, використовуючи критерій середнього абсолютного відхилення, стандартного відхилення та середнього стандартного відхилення в точиі кипіння. Показано, щьо модель NRTL задовільно корелює з даними ПРP.

Ключові слова: 2-азидо-N,N-диметилетанамін, парорідинна рівновага, азеотроп, NRTL. 